\title{
Kisspeptin and KISS1R: a critical pathway in the reproductive system
}

\author{
Elena Gianetti and Stephanie Seminara \\ Reproductive Endocrine Unit, Massachusetts General Hospital, 55 Fruit Street, BHX 5, Boston, Massachusetts \\ 02114, USA
}

Correspondence should be addressed to E Gianetti; Email: egianetti@partners.org

\begin{abstract}
In 2003, three groups around the world simultaneously discovered that KISS1R (GPR54) is a key gatekeeper of sexual maturation in both mice and men. Developmental changes in the expression of the ligand for KISS1R, kisspeptin, support its critical role in the pubertal transition. In addition, kisspeptin, a powerful stimulus of GNRH-induced gonadotropin secretion and may modulate both positive and negative sex steroid feedback effects at the hypothalamic level. Genetic studies in humans have revealed both loss-of-function and gainof-function mutations in patients with idiopathic hypogonadotropic hypogonadism and precocious puberty respectively. This review examines the kisspeptin/KISS1R pathway in the reproductive system.

Reproduction (2008) 136 295-301
\end{abstract}

\section{Introduction}

Human puberty is a mystifying process involving a complex series of hormonal events. The onset of puberty is marked by an increase in the secretion of gonadotropin-releasing hormone $(\mathrm{GNRH})$ from the hypothalamus. Pulsatile secretion of GNRH triggers the release of the gonadotropins such as follicle-stimulating hormone (FSH) and luteinizing hormone ( $\mathrm{LH})$ from the pituitary gland that in turn stimulates the production of sex steroids by the gonads. Sex steroids exert negative feedback effects at both the hypothalamus and pituitary with the exception of estrogen that undergoes positive feedback at the time of the mid-cycle ovulatory surge.

Studies conducted in the 1980s and 1990s identified some of the central players in the inhibitory and stimulatory controls of the GNRH pulse generator (Kaufman et al. 1985, Terasawa \& Fernandez 2001, Grumbach 2002, Ojeda et al. 2003, Plant \& Barker-Gibb 2004). It seems likely that a large number of different neurotransmitters are involved in modulating the behavior of the GNRH neuron (Todman et al. 2005). The GABAergic neuronal system appears to be a substrate for 'central inhibition' in primates (Terasawa 2005). When GABA inhibition is removed or decreased, stimulatory input from glutamatergic neurons as well as norepinephrine and neuropeptide $Y$ (NPY) neurons become active (Jarry et al. 1988, Terasawa \& Fernandez 2001). In addition to neurotransmitters, more recently, glial cell regulation mechanisms have also been implicated in the activation of the GNRH neurons
(Ojeda et al. 2003). The search for additional signals that herald the change in GNRH dynamics during puberty has continued in recent years with a genetic twist. These efforts, discussed in greater detail below, led to the discovery of the newest players in the regulation of GNRH secretion: kisspeptin and its receptor, KISS1R (previously known as GPR54).

\section{KISS1R and its ligand kisspeptin}

Although genetic studies ultimately placed KISS1R on the map as a key modulator of GNRH secretion, the biological life of KISS1R did not begin in reproduction. A member of the rhodopsin family of G-protein-coupled receptors, GPR54, was originally cloned in 1999 and was an orphan receptor until 2001 when its ligand was discovered to derive from kisspeptin (Kotani et al. 2001, Muir et al. 2001, Ohtaki et al. 2001). The longest peptide (kisspeptin 1 68-121) is known as 'metastin' but shorter C-terminal peptides share similar affinities and efficacies. The gene encoding kisspeptin, KISS1, has been localized to chromosome 1 and codes for a 145-amino acid protein that can be cleaved to form different length kisspeptins (West et al. 1998). C-terminal fragments have been shown to be potent KISS1R agonists (Kotani et al. 2001, Muir et al. 2001).

Interestingly, the original niche for kisspeptin was in cancer biology as it was isolated as a tumor metastasis suppressor gene in a human malignant melanoma cell line (Lee et al. 1996, Lee \& Welch 1997a). Kisspeptin can suppress the metastatic potential of melanoma and breast cancer cell lines in vivo (Lee et al. 1996, Lee \& 
Welch 1997b). More recently, the expression levels of KISS1 have been found to be reduced in several, but not all, metastatic cancer specimens (Lee \& Welch 1997b, Shirasaki et al. 2001, Sanchez-Carbayo et al. 2003, Dhar et al. 2004, Ikeguchi et al. 2004, Masui et al. 2004, Jiang et al. 2005, Ohta et al. 2005, Zohrabian et al. 2007).

\section{Kisspeptin and pregnancy}

While a relationship between kisspeptin's metastasis suppressor properties and the neuroendocrine role is not yet clear, high levels of kisspeptin have been discovered in the peripheral blood of pregnant women (Horikoshi et al. 2003). Moreover, prominent expression of KISS1R and kisspeptin has been demonstrated in human placenta at higher levels during the first trimester of pregnancy in comparison with the term placenta (Janneau et al. 2002). In fact, kisspeptin inhibits trophoblast invasion during placental formation (Bilban et al. 2004). Interestingly, decreased levels of both kisspeptin and KISS1R mRNA have been found in choriocarcinoma cells, thus suggesting an important link between kisspeptin action and trophoblast invasion during early pregnancy (Janneau et al. 2002).

\section{Kisspeptin/KISS1R critical for puberty}

The reproductive dimension of the kisspeptin/KISS1R system was revealed in late 2003, when two groups independently reported the presence of deletions and inactivating mutations of KISS1R in patients with idiopathic hypogonadotropic hypogonadism (IHH), a condition characterized by low sex steroids and gonadotropin levels (de Roux et al. 2003, Seminara et al. 2003). Along with the reporting of the lossof-function mutations in humans, phenotypic characterization of mice with targeted deletion of Kiss $1 r$ was also described (Funes et al. 2003, Seminara et al. 2003). The Kiss $1 r$ knockout mice also displayed hypogonadotropic hypogonadism, demonstrating parallelism to the human disease model. In total, the linkage studies, in vitro assays, and mouse characterization established that KISS1R and its ligand play a fundamental role in the control of reproductive function in mammals.

Following these genetic discoveries, the pathway encompassed by kisspeptin and its receptor, KISS1R, has been the focus of intense study by investigators across several disciplines. The remainder of this review will explore the various models, particularly in vivo, that have led to the remarkable exposition of the reproductive roles of kisspeptin and KISS1R.

\section{Differential hypothalamic expression}

Several studies have explored the distribution and temporal patterns of kisspeptin expression. Kisspeptin-expressing neurons are present in the arcuate nucleus (Arc), the periventricular nucleus (PeN), and the anteroventral periventricular nucleus (AVPV) in mice (Gottsch et al. 2004, Smith et al. 2005a, 2005b). Additional, but more subtle, expression is seen in the anterodorsal preoptic area and the bed nucleus of the stria terminalis.

Kisspeptin appears to undergo differential expression in distinct hypothalamic nuclei. Kisspeptin expression in the AVPV is sexually dimorphic, with much greater expression in females (Smith et al. 2005b). Gonadectomy increases the number of detectable Kiss 1 mRNAexpressing neurons as well as the content of Kiss1 mRNA per cell in the Arc. Sex steroid replacement reduces Kiss 1 expression back to that of intact animals (Smith et al. 2005a, 2005b). These observations suggest that kisspeptin may modulate the negative feedback on GNRH secretion exerted by sex steroids. By contrast, gonadectomy decreases Kiss 1 expression in the AVPV and sex steroid replacement restores it. This suggests that kisspeptin participates in the positive feedback loop is seen in the female estrous cycle (Smith et al. 2005a, 2005b). Indeed, administration of kisspeptin-blocking antibodies to the brains of female rats blocks the midcycle LH surge (Adachi et al. 2007). Therefore, sex steroids appear to play a major role in kisspeptin expression, though many questions remain about how kisspeptin can stimulate transcription in one nucleus and repress it in another.

In contrast to the rodent, information on KISS1 expression in the human is still quite limited. In the infundibular nucleus (corresponding to the Arc), postmenopausal woman have a higher number of kisspeptinexpressing neurons, an increased size of the neurons, and an increased quantity of kisspeptin mRNA per cell when compared with premenopausal woman (Rometo et al. 2007), confirming also in humans a possible role of this nucleus in the negative feedback on GNRH exerted by estrogens. These results are consistent with data from ovariectomized cynomolgus monkeys (Rometo et al. 2007). Comprehensive studies on the expression of kisspeptin across the human reproductive development have yet to be performed.

In mice and monkeys, Kiss1 mRNA levels in the hypothalamus are low prior to sexual maturation but increase dramatically at the time of sexual development (Han et al. 2005, Shahab et al. 2005). Both male and female rats undergo considerable augmentation of hypothalamic Kiss1 mRNA expression during the transition from juvenile to adult life (Navarro et al. 2004a). More specifically, Kiss1 expression in the mouse AVPV (both number of neurons and kisspeptin content per cell) is greater in adult than in prepubertal animals (Han et al. 2005). In monkeys, KISS1 mRNA increases in the hypothalamus across sexual maturation in both agonalad males and intact females. KISS1R mRNA increases in intact females as well, suggesting that 
increased expression of this pathway is the key to the timing of sexual development (Shahab et al. 2005).

In addition to increase in kisspeptin expression, kisspeptin tone appears to play a pivotal role in the onset and pacing of reproductive development. In sexually immature female rats, chronic administration of kisspeptin ( 6 days) advances the timing of sexual maturation as evidenced by precocious vaginal opening (Navarro et al. 2004b). In the human, mutations within the kisspeptin/KISS1R pathway establish varying degrees of kisspeptin 'tone' with clear effects on the timing and pace of pubertal development. As mentioned earlier, loss-of-function mutations in the gene encoding kisspeptin's receptor, KISS1R, cause hypogonadotropic hypogonadism. Recently, a gain-of-function mutation in KISS1R has been identified in a patient with central precocious puberty (Teles et al. 2008). Therefore, kisspeptin is an indisputable gatekeeper of pubertal function.

\section{Impact of metabolic and environmental factors on kisspeptin expression}

Fasting has a well-known inhibitory effect on gonadotropin secretion and ovulation. Paradoxically, GNRH gene expression at the hypothalamus is not reduced in the fasted state (Bergendahl et al. 1992). This suggests that modifications of the hypothalamic-pituitary-gonadal axis in fasting occur upstream from the GNRH synthesis pathways. Because of the considerable data pointing to kisspeptin as a critical gatekeeper for GNRH neuronal function, the interplay between energy stores, kisspeptin expression, and activation of the reproductive cascade has been explored by some investigators. Shortterm fasting in male and female prepubertal rats simultaneously reduces Kiss 1 mRNA and increases Kiss $1 r$ mRNA levels compared with rats fed ad libitum (Castellano et al. 2005). Treatment with kisspeptin can restore indices of pubertal maturation in the majority of animals as well as reverse the suppressed gonadotropin and sex steroid levels. Leptin may be a link between the kisspeptin pathway and metabolism. The content of Kiss $1 \mathrm{mRNA}$ in the Arc is significantly reduced in ob/ob compared with WT mice, and partially restored by leptin administration (Smith et al. 2006). Moreover, almost a half of Kiss1 mRNA-expressing cells in the Arc express also leptin receptor mRNA, suggesting that kisspeptin is a key to the metabolic regulation of reproductive function (Smith et al. 2006).

Similar to undernutrition, uncontrolled diabetes in rodents is also characterized by decreased LH secretion (Jackson \& Hutson 1984, Steger et al. 1989, Dong et al. 1991, Sexton \& Jarow 1997). GNRH release is maintained in streptozotocin (STZ)-treated rats (Spindler- Vomachka \& Johnson 1985, Clough et al. 1998), suggesting that the defect underlying the hypogonadotropism in these animals lies upstream from the GNRH neurons. Moreover, kisspeptin administration stimulates LH release in STZtreated rats (Castellano et al. 2006). In turn, it has recently been shown that kisspeptin is able to reduce glucoseinduced insulin secretion (but not basal insulin levels) in a dose-dependent manner, probably through a direct effect on pancreatic B cells, profiling a diabetogenic role of kisspeptin (Silvestre et al. 2008). In animals that breed seasonally, the length of the light-darkness cycle has a potent effect on reproductive function. In sheep, changes in the light-darkness cycle have been shown to modulate KISS1 expression in the Arc. Specifically, the number of KISS1 mRNA-expressing cells is reduced during seasonal anestrus and augmented at the onset of the breeding season (Smith et al. 2007). Administration of kisspeptin to seasonally acyclic ewes can induce ovulation (Caraty et al. 2007). Kisspeptin, therefore, appears to mediate the effects of multiple modulators of the reproductive endocrine axis including metabolism, energy stores, and light-darkness cycles.

\section{Kisspeptin administration to intact animals: powerful stimulus to gonadotropin release}

Kisspeptin peptides are powerful stimulators of gonadotropin secretion in several mammalian species, including rodents (Gottsch et al. 2004, Matsui et al. 2004, Navarro et al. 2004a, 2004b, 2005a, 2005b, Thompson et al. 2004, Messager et al. 2005), sheep (Smith et al. 2007), monkeys (Shahab et al. 2005, Plant et al. 2006), and even humans (Dhillo et al. 2005). The stimulatory effect of kisspeptin is extraordinary high, as intracerebral doses as low as 100/fmol evoke nearly maximal LH responses (Gottsch et al. 2004). The effects of kisspeptin on LH can be completely abrogated by a GNRH antagonist, demonstrating that it is acting through the GNRH receptor to stimulate LH release (i.e., hypothalamic effect; Gottsch et al. 2004, Shahab et al. 2005). Kisspeptin is unable to stimulate $\mathrm{LH}$ release when given to Kiss $1 r$ knockout mice, suggesting that the stimulatory effects of this peptide are mediated only through this receptor (Messager et al. 2005).

\section{Method of administration}

In addition to timing and dose, the method of administration of kisspeptin may be equally critical in eliciting the gonadotropin response. Parallel to the classic experiments of Belchetz and Knobil with GNRH administration three decades ago (Belchetz et al. 1978), the mode of administration of kisspeptin (continuous versus intermittent) has profound effects on its ability to elicit gonadotropin secretion (Seminara et al. 2006). Continuous infusion of high-dose kisspeptin 112-121 (metastin 45-54) to juvenile, agonadal male rhesus monkeys initially stimulates $\mathrm{LH}$ release, but then abolishes the 
LH response (Seminara et al. 2006). The sustained suppression of LH levels during continuous exposure to kisspeptin is secondary to desensitization or downregulation of KISS1R.

The finding has not only physiological but also therapeutic implications. In clinical practice, reversible suppression of the pituitary-gonadal axis is often a desired endpoint in the treatment of certain reproductive cancers, endometriosis, and infertility. The fact that continuous kisspeptin administration can also bring about the suppression of LH levels, suggests that it (or its analogues) might be novel therapeutic possibilities for the treatment of reproductive disorders in the future.

\section{Return to genetics}

In 2001, $\sim 40 \%$ of probands with autosomal recessive normosmic hypogonadotropic hypogonadism $(\mathrm{IHH})$ and $10-17 \%$ of sporadic cases were found to harbor mutations in the $G N R H R$, the gene encoding the GNRH receptor (Beranova et al. 2001, Bo-Abbas et al. 2003). Clearly, additional genes were awaiting discovery.

As briefly described earlier in 2003, groups independently identified KISS1R as a gatekeeper of puberty (de Roux et al. 2003, Seminara et al. 2003). de Roux et al. (2003) recruited a consanguineous family in which five out of eight children had IHH. Seminara et al. (2003) studied a large Saudi Arabian family in which three marriages between first cousins produced six affected and thirteen unaffected offspring. In both pedigrees, a genome-wide scan led to evidence for linkage on chromosome 19 and ultimately the discovery of mutations in KISS1R. Since 2003, other loss-of-function KISS1R mutations have been discovered and characterized (de Roux et al. 2003, Seminara et al. 2003,
Lanfranco et al. 2005, Semple et al. 2005, TenenbaumRakover et al. 2007). Mutations in KISS1R span the length of the receptor without a 'hotspot' (Fig. 1).

Although the number of KISS1R mutations reported in the literature is small, there are some unifying characteristics in the patients who harbor them. Anosmia, midline facial defects, and skeletal anomalies do not figure prominently. All individuals with homozygous or compound heterozygote mutations fail to undergo pubertal development, while heterozygous family members are devoid of obvious reproductive phenotypes. Patients with KISS1R mutations retain responsiveness to both exogenous pulsatile GNRH and gonadotropins (Seminara et al. 2003, Pallais et al. 2006). During 10-min blood sampling, low-amplitude LH pulses can still be detected in patients with KISS1R mutations (Seminara et al. 2003, Pallais et al. 2006). Therefore, loss-of-function mutations seem to reduce GNRH without interfering with the intrinsic $\mathrm{GNRH}$ pulse generator (de Roux et al. 2003, Seminara et al. 2003).

As with GNRHR mutations, the prevalence of KISS1R mutations is higher among familial than non-familial probands. However, mutations are much more common in GNRHR than in KISS1R (Cerrato et al. 2006). Considering GNRH and KISS1R together, it is reasonable for patients with normosmic $\mathrm{IHH}$ undergo genetic screening.

If loss-of-function mutations in KISS1R cause $\mathrm{IHH}$, could gain-of-function mutations cause central precocious puberty? Recently, a new KISS1R mutation (R385P) was identified in an 8-year-old adopted Brazilian female with precocious puberty (Teles et al. 2008). In in vitro studies, the mutated receptor was found to exhibit prolonged activation of second messenger signaling pathways compared with wild-type KISS1R.



Figure 1 The currently known mutations in the human KISS1R gene. 


\section{Targeted deletion of Kiss1r and Kiss1}

In general, both $\mathrm{Kiss}_{1} \mathrm{r}^{-/-}$and $\mathrm{Kiss} \mathrm{1}^{-/-}$mice mirror their human counterparts with abnormal sexual development (Funes et al. 2003, Seminara et al. 2003, d'Anglemont de Tassigny et al. 2007, Lapatto et al. 2007). Female mutants have delayed vaginal opening, whereas mutant males have shorter anogenital distance. Mutant mice of both sexes exhibit small gonads, reduced levels of FSH and $\mathrm{LH}$, and infertility. Despite these markers of hypogonadism, there are some interesting paradoxes in the mice. Both Kiss $1 r^{-/-}$and Kiss $1^{-/-}$ male knockouts demonstrate spermatogenesis although it is impaired ( $\mathrm{d}^{\prime}$ Anglemont de Tassigny et al. 2007, Lapatto et al. 2007). In addition, some female mutant mice exhibit partial sexual maturation, with about half of $\mathrm{Kiss}^{-1-}$ females and a smaller proportion of Kiss $1 \mathrm{r}^{-1-}$ females demonstrating persistent vaginal cornification (Lapatto et al. 2007). Detailed studies of estrous cycling and sexual behavior will be required to fully understand the phenotypes of these animals.

In conclusion, the kisspeptin/KISS1R system has been demonstrated to have a crucial role in the initiation of sexual maturation across mammalian species and maintenance of the normal reproductive function. Further studies will continue to elucidate the richness and complexity underlying the biology of the pathway. In addition, understanding kisspeptin and KISS1R physiology may aid the development of new reproductive therapies.

\section{Declaration of interest}

The authors declare that there is no conflict of interest that would prejudice the impartiality of this scientific work.

\section{References}

Adachi S, Yamada S, Takatsu Y, Matsui H, Kinoshita M, Takase K, Sugiura H, Ohtaki T, Matsumoto H, Uenoyama Y et al. 2007 Involvement of anteroventral periventricular metastin/kisspeptin neurons in estrogen positive feedback action on luteinizing hormone release in female rats. Journal of Reproduction and Development 53 367-378.

Belchetz PE, Plant TM, Nakai Y, Keogh EJ \& Knobil E 1978 Hypophysial responses to continuous and intermittent delivery of hypopthalamic gonadotropin-releasing hormone. Science 202 631-633.

Beranova $M$, Oliveira LM, Bédécarrats GY, Schipani $E$, Vallejo $M$, Ammini AC, Quintos JB, Hall JE, Martin KA, Hayes FJ et al. 2001 Prevalence, phenotypic spectrum, and modes of inheritance of gonadotropin-releasing hormone receptor mutations in idiopathic hypogonadotropic hypogonadism. Journal of Clinical Endocrinology and Metabolism 86 1580-1588.

Bergendahl M, Wiemann JN, Clifton DK, Huhtaniemi I \& Steiner RA 1992 Short-term starvation decreases POMC mRNA but does not alter GnRH mRNA in rat brain. Neuroendocrinology 56 913-920.

Bilban M, Ghaffari-Tabrizi N, Hintermann E, Bauer S, Molzer S, Zoratti C, Malli R, Sharabi A, Hiden U, Graier W et al. 2004 Kisspeptin-10, a KiSS$1 /$ metastin-derived decapeptide, is a physiological invasion inhibitor of primary human trophoblasts. Journal of Cell Science 117 1319-1328.

Bo-Abbas Y, Acierno JS Jr, Shagoury JK, Crowley WF Jr \& Seminara SB 2003 Autosomal recessive idiopathic hypogonadotropic hypogonadism: genetic analysis excludes mutations in the gonadotropin-releasing hormone $(\mathrm{GnRH})$ and $\mathrm{GnRH}$ receptor genes. Journal of Clinical Endocrinology and Metabolism 88 2730-2737.

Caraty A, Smith JT, Lomet D, Ben Saïd S, Morrissey A, Cognie J, Doughton B, Baril G, Briant C \& Clarke IJ 2007 Kisspeptin synchronizes preovulatory surges in cyclical ewes and causes ovulation in seasonally acyclic ewes. Endocrinology 148 5258-5267.

Castellano JM, Navarro VM, Fernández-Fernández R, Nogueiras $\mathbf{R}$, Tovar $\mathbf{S}$, Roa J, Vazquez MJ, Vigo E, Casanueva FF, Aguilar E et al. 2005 Changes in hypothalamic KiSS-1 system and restoration of pubertal activation of the reproductive axis by kisspeptin in undernutrition. Endocrinology $\mathbf{1 4 6}$ 3917-3925.

Castellano JM, Navarro VM, Fernández-Fernández R, Roa J, Vigo E, Pineda R, Dieguez C, Aguilar E, Pinilla L \& Tena-Sempere M 2006 Expression of hypothalamic KiSS-1 system and rescue of defective gonadotropic responses by kisspeptin in streptozotocin-induced diabetic male rats. Diabetes 55 2602-2610.

Cerrato F, Shagoury J, Kralickova M, Dwyer A, Falardeau J, Ozata M, Van Vliet G, Bouloux P, Hall JE, Hayes FJ et al. 2006 Coding sequence analysis of GNRHR and GPR54 in patients with congenital and adultonset forms of hypogonadotropic hypogonadism. European Journal of Endocrinology 155 (Supplement 1) S3-S10.

Clough RW, Kienast SG \& Steger RW 1998 Reproductive endocrinopathy in acute streptozotocin-induced diabetic male rats. Studies on LHRH. Endocrine 8 37-43.

d'Anglemont de Tassigny X, Fagg LA, Dixon JP, Day K, Leitch HG, Hendrick AG, Zahn D, Franceschini I, Caraty A, Carlton MB et al. 2007 Hypogonadotropic hypogonadism in mice lacking a functional Kiss 1 gene. PNAS 104 10714-10719.

Dhar DK, Naora H, Kubota H, Maruyama R, Yoshimura H, Tonomoto $Y$, Tachibana M, Ono T, Otani H \& Nagasue N 2004 Downregulation of KiSS-1 expression is responsible for tumor invasion and worse prognosis in gastric carcinoma. International Journal of Cancer 111 868-872.

Dhillo WS, Chaudhri OB, Patterson M, Thompson EL, Murphy KG, Badman MK, McGowan BM, Amber V, Patel S, Ghatei MA et al. 2005 Kisspeptin-54 stimulates the hypothalamic-pituitary gonadal axis in human males. Journal of Clinical Endocrinology and Metabolism 90 6609-6615.

Dong Q, Lazarus RM, Wong LS, Vellios M \& Handelsman DJ 1991 Pulsatile $\mathrm{LH}$ secretion in streptozotocin-induced diabetes in the rat. Journal of Endocrinology 131 49-55.

Funes S, Hedrick JA, Vassileva G, Markowitz L, Abbondanzo S, Golovko A, Yang S, Monsma FJ \& Gustafson EL 2003 The KiSS-1 receptor GPR54 is essential for the development of the murine reproductive system. Biochemical and Biophysical Research Communications 312 1357-1363.

Gottsch ML, Cunningham MJ, Smith JT, Popa SM, Acohido BV, Crowley WF, Seminara S, Clifton DK \& Steiner RA 2004 A role for kisspeptins in the regulation of gonadotropin secretion in the mouse. Endocrinology 145 4073-4077.

Grumbach MM 2002 The neuroendocrinology of human puberty revisited. Hormone Research 57 2-14.

Han SK, Gottsch ML, Lee KJ, Popa SM, Smith JT, Jakawich SK, Clifton DK, Steiner RA \& Herbison AE 2005 Activation of gonadotropin-releasing hormone neurons by kisspeptin as a neuroendocrine switch for the onset of puberty. Journal of Neuroscience 25 11349-11356.

Horikoshi Y, Matsumoto H, Takatsu Y, Ohtaki T, Kitada C, Usuki S \& Fujino M 2003 Dramatic elevation of plasma metastin concentrations in human pregnancy: metastin as a novel placenta-derived hormone in humans. Journal of Clinical Endocrinology and Metabolism 88 914-919.

Ikeguchi M, Yamaguchi K \& Kaibara N 2004 Clinical significance of the loss of KiSS-1 and orphan G-protein-coupled receptor (hOT7T175) gene expression in esophageal squamous cell carcinoma. Clinical Cancer Research 10 1379-1383.

Jackson FL \& Hutson JC 1984 Altered responses to androgen in diabetic male rats. Diabetes 33 819-824.

Janneau JL, Maldonado-Estrada J, Tachdjian G, Miran I, Motté N, Saulnier P, Sabourin JC, Coté JF, Simon B, Frydman R et al. 2002 Transcriptional expression of genes involved in cell invasion and migration by normal and tumoral trophoblast cells. Journal of Clinical Endocrinology and Metabolism 87 5336-5339. 
Jarry H, Perschl A \& Wuttke W 1988 Further evidence that preoptic anterior hypothalamic GABAergic neurons are part of the $\mathrm{GnRH}$ pulse and surge generator. Acta Endocrinologica 118 573-579.

Jiang Y, Berk M, Singh LS, Tan H, Yin L, Powell CT \& Xu Y 2005 KiSS1 suppresses metastasis in human ovarian cancer via inhibition of protein kinase C alpha. Clinical \& Experimental Metastasis 22 369-376.

Kaufman JM, Kesner JS, Wilson RC \& Knobil E 1985 Electrophysiological manifestation of luteinizing hormone-releasing hormone pulse generator activity in the rhesus monkey: influence of alpha-adrenergic and dopaminergic blocking agents. Endocrinology 116 1327-1333.

Kotani M, Detheux M, Vandenbogaerde A, Communi D, Vanderwinden JM, Le Poul E, Brézillon S, Tyldesley R, Suarez-Huerta N, Vandeput F et al. 2001 The metastasis suppressor gene KiSS-1 encodes kisspeptins, the natural ligands of the orphan G protein-coupled receptor GPR54. Journal of Biological Chemistry 276 34631-34636.

Lanfranco F, Gromoll J, von Eckardstein S, Herding EM, Nieschlag E \& Simoni M 2005 Role of sequence variations of the GnRH receptor and G protein-coupled receptor 54 gene in male idiopathic hypogonadotropic hypogonadism. European Journal of Endocrinology 153 845-852.

Lapatto R, Pallais JC, Zhang D, Chan YM, Mahan A, Cerrato F, Le WW, Hoffman GE \& Seminara SB 2007 Kiss1/mice exhibit more variable hypogonadism than gpr54/mice. Endocrinology 148 4927-4936.

Lee JH \& Welch DR 1997a Identification of highly expressed genes in metastasis-suppressed chromosome 6/human malignant melanoma hybrid cells using subtractive hybridization and differential display. International Journal of Cancer 71 1035-1044.

Lee JH \& Welch DR $1997 b$ Suppression of metastasis in human breast carcinoma MDA-MB-435 cells after transfection with the metastasis suppressor gene, KiSS-1. Cancer Research 57 2384-2387.

Lee JH, Miele ME, Hicks DJ, Phillips KK, Trent JM, Weissman BE \& Welch DR 1996 KiSS-1, a novel human malignant melanoma metastasissuppressor gene. Journal of the National Cancer Institute 88 1731-1737.

Masui T, Doi R, Mori T, Toyoda E, Koizumi M, Kami K, Ito D, Peiper SC, Broach JR, Oishi S et al. 2004 Metastin and its variant forms suppress migration of pancreatic cancer cells. Biochemical and Biophysical Research Communications 315 85-92.

Matsui H, Takatsu Y, Kumano S, Matsumoto H \& Ohtaki T 2004 Peripheral administration of metastin induces marked gonadotropin release and ovulation in the rat. Biochemical and Biophysical Research Communications 320 383-388.

Messager S, Chatzidaki EE, Ma D, Hendrick AG, Zahn D, Dixon J, Thresher RR, Malinge I, Lomet D, Carlton MB et al. 2005 Kisspeptin directly stimulates gonadotropin-releasing hormone release via G protein-coupled receptor 54. PNAS 102 1761-1766.

Muir Al, Chamberlain L, Elshourbagy NA, Michalovich D, Moore DJ, Calamari A, Szekeres PG, Sarau HM, Chambers JK, Murdock P et al. 2001 AXOR12, a novel human G protein-coupled receptor, activated by the peptide KiSS-1. Journal of Biological Chemistry 276 28969-28975.

Navarro VM, Castellano JM, Fernández-Fernández R, Barreiro ML, Roa J, Sanchez-Criado JE, Aguilar E, Dieguez C, Pinilla L \& Tena-Sempere M 2004a Developmental and hormonally regulated messenger ribonucleic acid expression of KiSS-1 and its putative receptor, GPR54, in rat hypothalamus and potent luteinizing hormone-releasing activity of KiSS-1 peptide. Endocrinology 145 4565-4574.

Navarro VM, Fernández-Fernández R, Castellano JM, Roa J, Mayen A, Barreiro ML, Gaytan F, Aguilar E, Pinilla L, Dieguez C et al. 2004b Advanced vaginal opening and precocious activation of the reproductive axis by KiSS-1 peptide, the endogenous ligand of GPR54. Journal of Physiology 561 379-386.

Navarro VM, Castellano JM, Fernández-Fernández R, Tovar S, Roa J, Mayen A, Barreiro ML, Casanueva FF, Aguilar E, Dieguez C et al. 2005a Effects of KiSS-1 peptide, the natural ligand of GPR54, on folliclestimulating hormone secretion in the rat. Endocrinology 146 1689-1697.

Navarro VM, Castellano JM, Fernández-Fernández R, Tovar S, Roa J, Mayen A, Nogueiras R, Vazquez MJ, Barreiro ML, Magni P et al. 2005b Characterization of the potent luteinizing hormone-releasing activity of KiSS-1 peptide, the natural ligand of GPR54. Endocrinology 146 156-163.

Ohta S, Lai EW, Pang AL, Brouwers FM, Chan WY, Eisenhofer G, de Krijger R, Ksinantova L, Breza J, Blazicek P et al. 2005 Downregulation of metastasis suppressor genes in malignant pheochromocytoma. International Journal of Cancer 114 139-143.
Ohtaki T, Shintani Y, Honda S, Matsumoto H, Hori A, Kanehashi K, Terao Y, Kumano S, Takatsu Y, Masuda Y et al. 2001 Metastasis suppressor gene KiSS-1 encodes peptide ligand of a G-protein-coupled receptor. Nature 411 613-617.

Ojeda SR, Prevot V, Heger S, Lomniczi A, Dziedzic B \& Mungenast A 2003 Glia-to-neuron signaling and the neuroendocrine control of female puberty. Annals of Medicine 35 244-255.

Pallais JC, Bo-Abbas Y, Pitteloud N, Crowley WF Jr \& Seminara SB 2006 Neuroendocrine, gonadal, placental, and obstetric phenotypes in patients with $\mathrm{IHH}$ and mutations in the G-protein coupled receptor, GPR54. Molecular and Cellular Endocrinology 254-255 70-77.

Plant TM \& Barker-Gibb ML 2004 Neurobiological mechanisms of puberty in higher primates. Human Reproduction Update 10 67-77.

Plant TM, Ramaswamy S \& Dipietro MJ 2006 Repetitive activation of hypothalamic G protein-coupled receptor 54 with intravenous pulses of kisspeptin in the juvenile monkey (Macaca mulatta) elicits a sustained train of gonadotropin-releasing hormone discharges. Endocrinology 147 1007-1013.

Rometo AM, Krajewski SJ, Voytko ML \& Rance NE 2007 Hypertrophy and increased kisspeptin gene expression in the hypothalamic infundibular nucleus of postmenopausal women and ovariectomized monkeys. Journal of Clinical Endocrinology and Metabolism 92 2744-2750.

de Roux N, Genin E, Carel JC, Matsuda F, Chaussain JL \& Milgrom E 2003 Hypogonadotropic hypogonadism due to loss of function of the KiSS1derived peptide receptor GPR54. PNAS 100 10972-10976.

Sanchez-Carbayo M, Capodieci P \& Cordon-Cardo C 2003 Tumor suppressor role of KiSS-1 in bladder cancer: loss of KiSS-1 expression is associated with bladder cancer progression and clinical outcome. American Journal of Pathology 162 609-617.

Seminara SB, Messager S, Chatzidaki EE, Thresher RR, Acierno JS Jr, Shagoury JK, Bo-Abbas Y, Kuohung W, Schwinof KM, Hendrick AG et al. 2003 The GPR54 gene as a regulator of puberty. New England Journal of Medicine 349 1614-1627.

Seminara SB, Dipietro MJ, Ramaswamy S, Crowley WF Jr \& Plant TM 2006 Continuous human metastin 45-54 infusion desensitizes G proteincoupled receptor 54-induced gonadotropin-releasing hormone release monitored indirectly in the juvenile male Rhesus monkey (Macaca mulatta): a finding with therapeutic implications. Endocrinology 147 2122-2126.

Semple RK, Achermann JC, Ellery J, Farooqi IS, Karet FE, Stanhope RG, O'rahilly S \& Aparicio SA 2005 Two novel missense mutations in $g$ protein-coupled receptor 54 in a patient with hypogonadotropic hypogonadism. Journal of Clinical Endocrinology and Metabolism 90 1849-1855.

Sexton WJ \& Jarow JP 1997 Effect of diabetes mellitus upon male reproductive function. Urology $\mathbf{4 9} 508-513$.

Shahab M, Mastronardi C, Seminara SB, Crowley WF, Ojeda SR \& Plant TM 2005 Increased hypothalamic GPR54 signaling: a potential mechanism for initiation of puberty in primates. PNAS $\mathbf{1 0 2} 2129-2134$.

Shirasaki F, Takata M, Hatta N \& Takehara K 2001 Loss of expression of the metastasis suppressor gene KiSS1 during melanoma progression and its association with LOH of chromosome 6q16.3-q23. Cancer Research 61 $7422-7425$.

Silvestre RA, Egido EM, Hernández R \& Marco J 2008 Kisspeptin-13 inhibits insulin secretion without affecting glucagon or somatostatin release: study in the perfused rat pancreas. Journal of Endocrinology 196 283-290.

Smith JT, Cunningham MJ, Rissman EF, Clifton DK \& Steiner RA 2005a Regulation of Kiss1 gene expression in the brain of the female mouse. Endocrinology 146 3686-3692.

Smith JT, Dungan HM, Stoll EA, Gottsch ML, Braun RE, Eacker SM, Clifton DK \& Steiner RA 2005b Differential regulation of KiSS-1 mRNA expression by sex steroids in the brain of the male mouse. Endocrinology $1462976-2984$.

Smith JT, Acohido BV, Clifton DK \& Steiner RA 2006 KiSS-1 neurones are direct targets for leptin in the ob/ob mouse. Journal of Neuroendocrinology 18 298-303.

Smith JT, Clay CM, Caraty A \& Clarke IJ 2007 KiSS-1 messenger ribonucleic acid expression in the hypothalamus of the ewe is regulated by sex steroids and season. Endocrinology 148 1150-1157.

Spindler-Vomachka M \& Johnson DC 1985 Altered hypothalamic-pituitary function in the adult female rat with streptozotocin-induced diabetes. Diabetologia 28 38-44. 
Steger RW, Amador A, Lam E, Rathert J, Weis J \& Smith MS 1989 Streptozotocin-induced deficits in sex behavior and neuroendocrine function in male rats. Endocrinology 124 1737-1743.

Teles MG, Bianco SD, Brito VN, Trarbach EB, Kuohung W, Xu S, Seminara SB, Mendonca BB, Kaiser UB \& Latronico AC 2008 A GPR54-activating mutation in a patient with central precocious puberty. New England Journal of Medicine 358 709-715.

Tenenbaum-Rakover Y, Commenges-Ducos M, lovane A, Aumas C, Admoni O \& de Roux N 2007 Neuroendocrine phenotype analysis in five patients with isolated hypogonadotropic hypogonadism due to a L102P inactivating mutation of GPR54. Journal of Clinical Endocrinology and Metabolism 92 1137-1144.

Terasawa E 2005 Role of GABA in the mechanism of the onset of puberty in non-human primates. International Review of Neurobiology 71 113-129.

Terasawa E \& Fernandez DL 2001 Neurobiological mechanisms of the onset of puberty in primates. Endocrine Reviews 22 111-151.

Thompson EL, Patterson M, Murphy KG, Smith KL, Dhillo WS, Todd JF, Ghatei MA \& Bloom SR 2004 Central and peripheral administration of kisspeptin-10 stimulates the hypothalamic-pituitary-gonadal axis. Journal of Neuroendocrinology 16 850-858.
Todman MG, Han SK \& Herbison AE 2005 Profiling neurotransmitter receptor expression in mouse gonadotropin-releasing hormone neurons using green fluorescent protein-promoter transgenics and microarrays. Neuroscience 132 703-712.

West A, Vojta PJ, Welch DR \& Weissman BE 1998 Chromosome localization and genomic structure of the KiSS-1 metastasis suppressor gene (KISS1). Genomics 54 145-148.

Zohrabian VM, Nandu H, Gulati N, Khitrov G, Zhao C, Mohan A, Demattia J, Braun A, Das K, Murali R et al. 2007 Gene expression profiling of metastatic brain cancer. Oncology Reports 18 321-328.

Received 28 February 2008

First decision 27 March 2008

Revised manuscript received 6 May 2008

Accepted 21 May 2008 